\title{
Bacterial peritonitis caused by Listeria monocytogenes: Case report and review of the literature
}

\author{
JOE S DYLEWSKI FRCP
}

\begin{abstract}
IS DyLEwski. Bacterial peritonitis caused by Listeria monocytogenes: Case report and review of the literature. Can J Infect Dis 1996;7(1):59-62. Although Listeria monocytogenes has been isolated from the gastrointestinal tract, it is an infrequent cause of bacterial peritonitis. Since 1963 only 23 cases of peritonitis caused by listeria have been reported. This report describes another case in a patient with cirrhosis and chronic renal failure and presents a review of the literature. Most (16) of the previous cases were cirrhotic while six were undergoing chronic ambulatory peritoneal dialysis. Eight patients were on immunosuppressive therapy. Blood cultures were positive in fewer than half (42\%) of the cases and Gram stain of peritoneal fluid was positive only twice. The peritoneal fluid protein concentration was relatively high compared with other causes of bacterial peritonitis. Ampicillin was the drug most commonly used for treatment, and the majority of patients survived the acute infection.
\end{abstract}

Key Words: Bacterial peritonitis, Listeria monocytogenes

\section{Péritonite bactérienne causée par Listeria monocytogenes : rapport de cas et revue de la littérature}

RÉSUMÉ : Même si Listeria monocytogenes a été isolé dans les voies digestives, il est rarement en cause dans la péritonite bactérienne. Depuis 1963, 23 cas de péritonite à Listeria seulement ont été déclarés. Ce rapport décrit un autre cas, chez un patient cirrhotique et insuffisant rénal de longue date et présente une revue de la littérature. La plupart (16) des cas précédents touchaient des cirrhotiques, alors que six étaient sous dialyse péritonéale ambulatoire. Huit patients étaient sous traitement immuno-suppressif. Les hémocultures se sont révélées positives dans moins de la moitié des cas (42\%) et la coloration de Gram du liquide péritonéal n'a été positive que dans deux cas. La concentration protéique du liquide péritonéal était relativement élevée comparativement aux autres causes bactériennes de péritonite. L'ampicilline est le médicament le plus couramment employé et la majorité des patients survivent à l'infection aiguë.

L isteria monocytogenes is a Gram-positive rod that is most frequently associated with infections in neonates and in adults with impaired cell-mediated immunity. The most common clinical presentation of listeria infection has been sepsis and/or meningitis. Only 23 cases of peritonitis caused by this organism have been reported in the English literature since $1963(1-20)$. The majority of cases were described in patients with cirrhosis or in those undergoing chronic ambu-

Division of Microbiology and Infectious Diseases, St Mary's Hospital, Montreal, Quebec

Correspondence: Dr Joe Dylewski, St Mary's Hospital, 3830 Lacombe Avenue, Montreal, Quebec H3T 1M5. Telephone 514-345-3075, fax 514-345-3848

Received for publication November 30, 1994. Accepted March 25, 1995 
latory peritoneal dialysis (CAPD). A case of listeria peritonitis in a cirrhotic patient with coexisting chronic renal failure is reported along with a review of the literature.

\section{CASE PRESENTATION}

A 76-year-old male was admitted to hospital with a oneweek history of fever and increasing weakness. Past medical history included admissions for recurrent hepatic encephalopathy secondary to cryptogenic cirrhosis and chronic renal failure secondary to a proliferative glomerulonephritis. He had been on hemodialysis for five months and had recovered from an episode of Staphylococcus aureus septic arthritis of the left wrist three months before this admission. On examination his temperature was $38.7^{\circ} \mathrm{C}$ and he appeared lethargic but oriented. There was no asterixis and the neck was supple. Ascites was evident. Peripheral white blood cell count was $4 \times 10^{9} / \mathrm{L}$. Five sets of blood cultures were obtained over a $48 \mathrm{~h}$ period and a peritoneal tap was performed. White blood cells in ascitic fluid totalled $46 \times 10^{6} / \mathrm{L}$ (two neutrophils and 44 lymphocytes). On Gram stain no organisms were seen. The patient was observed for $48 \mathrm{~h}$ off antibiotics but did not improve. At this time the peritoneal fluid was reported as growing $E S$ cherichia coli and $L$ monocytogenes. A repeat peritoneal tap was performed and the cell count in the fluid was now $2850 \times 10^{6} / \mathrm{L}$ neutrophils and $350 \times 10^{6} / \mathrm{L}$ lymphocytes. Only listeria was isolated from this specimen. The patient was started on intravenous ampicillin $1 \mathrm{~g}$ every $6 \mathrm{~h}$ and treated for three weeks. A repeat peritoneal tap done after 10 days of treatment was sterile. All blood cultures taken before ampicillin was started were sterile. The patient initially responded to antibiotic therapy with resolution of fever, but two weeks after discontinuation of ampicillin he became more deeply jaundiced and then he developed a fatal upper gastrointestinal bleed. An autopsy was not performed.

\section{LITERATURE REVIEW}

MEDLINE was searched using index terms 'listeria infections' and 'peritonitis'. Additional cases were identified by review of the references found during the search. Twenty-three cases of listeria peritonitis have been reported in the English language literature since 1963 (Table 1). Including this case, there has been a male predominance (15 to nine) with an average age of 60 years (range 31 to 82 ). Sixteen patients suffered from cirrhosis and six were on CAPD. Eight patients were receiving some form of immunosuppressive therapy. Peripheral white blood cell count was greater than $10 \times 10^{9} / \mathrm{L}$ in only $50 \%$ of the cases. Peritoneal fluid white blood cell count ranged from $46 \times 10^{6}$ to $14,987 \times 10^{6} / \mathrm{L}$ and the mean protein concentration was $24 \mathrm{~g} / \mathrm{L}$ (range 0.8 to 49.0 ). Blood cultures were positive in eight of $19(42 \%)$ cases. One patient was diagnosed on the basis of a positive peritoneal biopsy done at laparoscopy. In only two cases did the Gram stain of ascitic fluid reveal Gram-positive rods. Nineteen patients received either ampicillin or amoxicillin as part of their treatment. Five deaths were reported with at least two being attributed to gastrointestinal bleeding. Three patients survived their acute infection only to succumb later to gastrointestinal bleeding.

\section{DISCUSSION}

Bacterial peritonitis may occur spontaneously or as the result of bowel perforation. Anaerobes and coliforms are the usual organisms isolated from cases of secondary bacterial peritonitis, while $E$ coli, $K$ pneumoniae and Streptococcus pneumoniae predominate in spontaneous bacterial peritonitis (SBP) (21). L monocytogenes is present in the gastrointestinal tract of up to $10 \%$ of healthy individuals (1) but it has only rarely been isolated from peritoneal fluid. In only one of the cases reviewed here was perforation of the bowel thought to lead directly to listeria peritonitis (13). Other possible mechanisms include spontaneous bacteremia or translocation of listeria into preexisting peritoneal fluid. Endoscopy may have precipitated the bacteremia in a few cases (20) although fewer than half had positive blood cultures. Outbreaks of listeria have been associated with ingestion of contaminated foods (22), and organisms may transmigrate the intestinal wall into ascitic fluid or peritoneal dialysate. Bacteria in peritoneal fluid may be eradicated by host defences by means of opsonins and macrophages. A low protein content of peritoneal fluid has correlated with an increased risk of acquiring SBP (23). This may be due to the absence of opsonins and other proteins, which then would allow a small inoculum of bacteria to multiply to numbers significant enough to produce disease (24). Over $50 \%$ of cases of SBP in one series had a peritoneal protein content of less than $5.0 \mathrm{~g} / \mathrm{L}(25)$. In this review of cases there was a relatively high peritoneal fluid protein content (mean $24 \mathrm{~g} / \mathrm{L}$ ). This difference may be because host defences against listeria depend more on lymphocyte and mononuclear phagocyte function than on opsonization.

The concomitant isolation of $E$ coli in the initial paracentesis is unusual; only one other case of listeria peritonitis (13) had additional bacteria isolated from the ascitic fluid. The inability to grow the $E$ coli on the repeat tap before therapy may reflect this patient's ability to neutralize this organism.

The clinical presentation of listeria peritonitis is similar to other causes of SBP in that fever, abdominal pain and change in mental status are the most common manifestations (18). Gram stain of peritoneal fluid was positive in only two cases; however, care must be taken not to disregard a report of Gram-positive rods present on stain or culture. Peritoneal fluid should be inoculated into blood culture bottles to enhance isolation (26). Treatment should involve either penicillin or ampicillin. Combination therapy with an aminoglycoside does not appear to be a necessity. Other antibiotics that have been used successfully include trimethoprim-sulfamethoxazole and erythromycin. Vancomycin failure has been reported (15). The duration of antibiotic therapy is not known, with most cases cured with two to three weeks of treatment.

\section{CONCLUSION}

Bacterial peritonitis caused by $L$ monocytogenes remains a rare occurrence but should be considered in patients with cirrhosis or in those on CAPD who develop fever, abdominal pain and a change in mental status. 


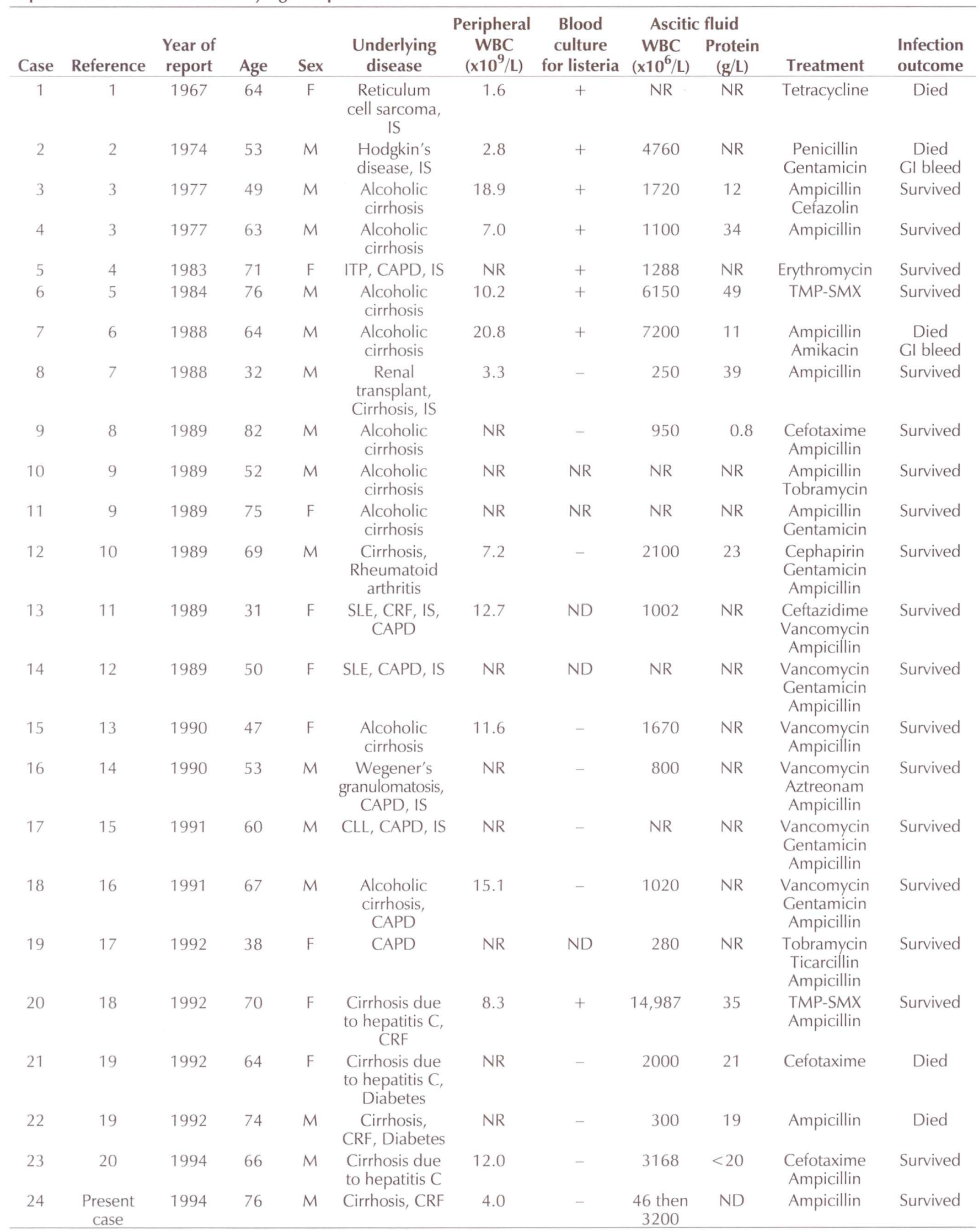




\section{ADDENDUM}

Since this paper was accepted for publication, an additional case of Listeria monocytogenes peritonitis has been reported in a 29-year-old female (27). Information on the characteristics of the peritoneal fluid was not not given. She was treated with ampicillin and an aminoglycoside and recovered.

\section{REFERENCES}

1. Louria DB, Hensle T, Armstrong D, et al. Listeriosis complicating malignant disease. Ann Intern Med 1967;67:261-81.

2. Case reports of the Massachussetts General Hospital. N Engl J Med 1974:291:516-24.

3. Rheingold OJ, Chiprut RO, Dickinson GM, Schiff ER. Spontaneous peritonitis of cirrhosis due to Listeria monocytogenes. Ann Intern Med 1977;87:455-6.

4. Myers JP, Peterson G, Rashid A. Peritonitis due to Listeria monocytogenes complicating continuous ambulatory peritoneal dialysis. J Infect Dis 1983;148:11-30.

5. Winslow DL, Steele ML. Listeria bacteremia and peritonitis associated with a peritoneovenous shunt: successful treatment with sulfamethoxazole and trimethoprim. J Infect Dis $1984 ; 149: 820$.

6. Soto-Hernandez JL, Nunley D, Gutierrez CC, Berk SL. Listeria monocytogenes peritonitis. Am J Gastroenterol 1988;83:180-2.

7. Larson CC, Baine WB, Ware AJ, Krejs GJ. Listeria peritonitis diagnosed by laparoscopy. Gastrointest Endosc 1988;34:352-4.

8. Lopez-San Roman A, Erdozain JC, Barcena R, Sanchez-Ruano JJ. Listeria monocytogenes peritonitis. An additional case. Am J Gastroenterol 1989;84:454-5. (Lett)

9. Pascual J, Sureda A, Boixeda D. Listeria monocytogenes spontaneous peritonitis. Am J Gastroenterol 1989;84:455. (Lett)

10. Curosh NA, Perednia DA. Listeria monocytogenes septic arthritis. A case report and review of the literature. Arch Intern Med 1989;149:1207-8.

11. Allais JM, Cavalieri SJ, Bierman MH, Clark RB. Listeria monocytogenes peritonitis in a patient on continuous ambulatory peritoneal dialysis. Nebr Med J 1989;74:303-5.

12. Korzets A, Andrews M, Campbell A, Feehally J, Walls J, Prentice M. Listeria monocytogenes peritonitis complicating CAPD. Perit Dial Int 1989;9:351-2.

13. Siegfried C, Schubert TT. Secondary bacterial peritonitis due to
Listeria monocytogenes after paracentesis. South Med J 1990;83:213-4.

14. al-Wali WI, Baillod R, Hamilton-Miller JM, Kyi MS, Brumfitt W. Listeria monocytogenes peritonitis during continuous ambulatory peritoneal dialysis. Postgrad Med J 1990;66:252. (Lett)

15. Dryden MS, Jones NF, Phillips I. Vancomycin therapy failure in Listeria monocytogenes peritonitis in a patient on continuous ambulatory peritoneal dialysis. J Infect Dis 1991;164:1239. (Lett)

16. Hart KA, Reiss-Levy EA, Trew PA. Listeria monocytogenes peritonitis associated with CAPD. Med J Aust 1991;154:59-60.

17. Lunde NM, Messana JM, Swartz RD. Unusual causes of peritonitis in patients undergoing continuous peritoneal dialysis with emphasis on Listeria monocytogenes. J Am Soc Nephrol 1992;3:1092-7.

18. Sivalingam JJ, Martin P, Fraimow HS, Yarze JC, Friedman LS. Listeria monocytogenes peritonitis; case report and literature review. Am J Gastroenterol 1992;87:1839-45.

19. Polanco A, Giner C, Canton R, et al. Spontaneous bacterial peritonitis caused by Listeria monocytogenes: two case reports and literature review. Eur J Clin Microbiol Infect Dis 1992;11:346-9.

20. Nguyen $\mathrm{MH}, \mathrm{Yu} \mathrm{VL}$. Listeria monocytogenes peritonitis in cirrhotic patients. Value of ascitic fluid Gram stain and a review of literature. Dig Dis Sci 1994;39:215-8.

21. Hoefs JC, Runyon BA. Spontaneous bacterial peritonitis. Dis Mon $1985 ; 31: 14$

22. Schlech WF, Lavigne PM, Bortolussi R, et al. Epidemic listeriosis - evidence for transmission by food. N Engl J Med 1983;308:203-6.

23. Runyon BA. Low-protein-concentration ascitic fluid is predisposed to spontaneous bacterial peritonitis. Gastroenterology 1986;91:1343-6.

24. Runyon BA. Patients with deficient ascitic fluid opsonic activity are predisposed to spontaneous bacterial peritonitis. Hepatology $1988 ; 8: 632-5$.

25. Runyon BA, Hoefs JC. Ascitic fluid analysis in the differentiation of spontaneous bacterial peritonitis from gastrointestinal tract perforation into ascitic fluid. Hepatology 1984;4:447-50.

26. Runyon BA, Umland RT, Merlin T. Inoculation of blood culture bottles with ascitic fluid. Improved detection of spontaneous bacterial peritonitis. Arch Intern Med 1987;147:73-5.

27. Miranda JA, Fontes J, Mozas J, Herruzo AJ, Miranda C. Listeria monocytogenes peritonitis during postpartum. Clin Microbiol Newsletter 1995;17:63-4. 


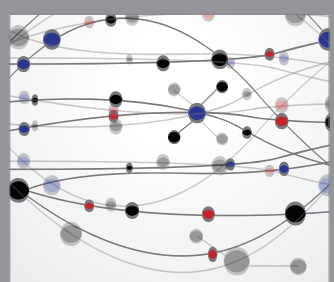

The Scientific World Journal
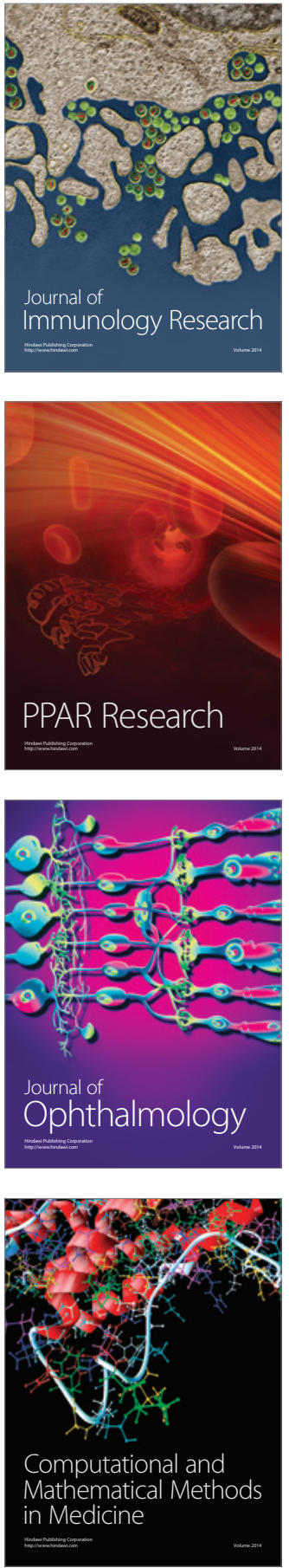

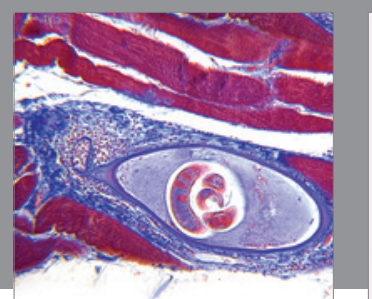

Gastroenterology Research and Practice

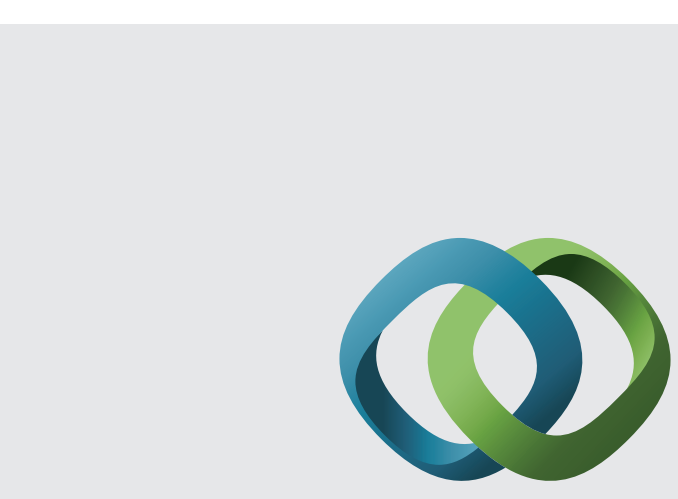

\section{Hindawi}

Submit your manuscripts at

http://www.hindawi.com
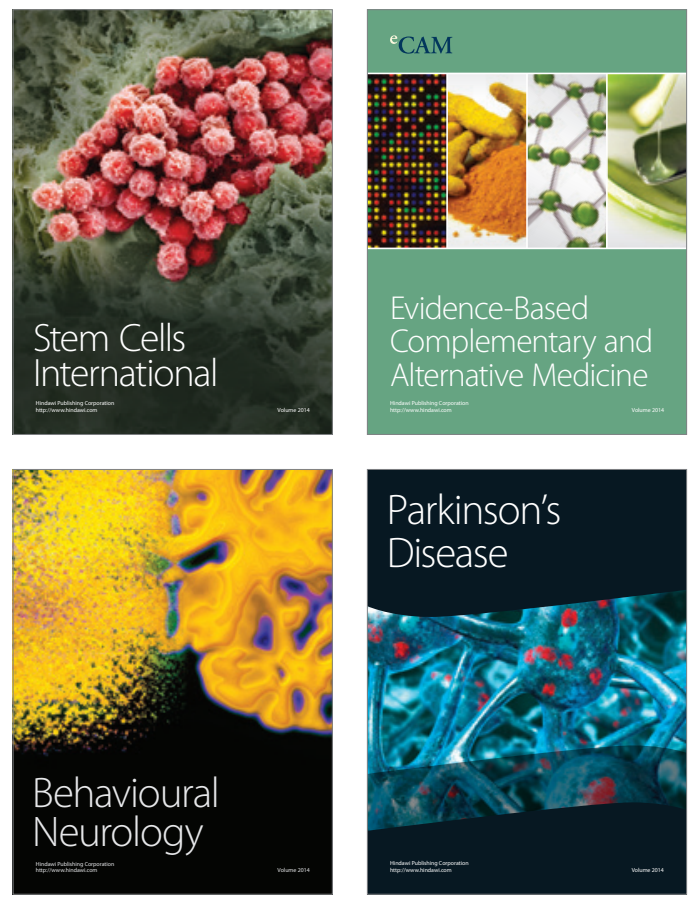
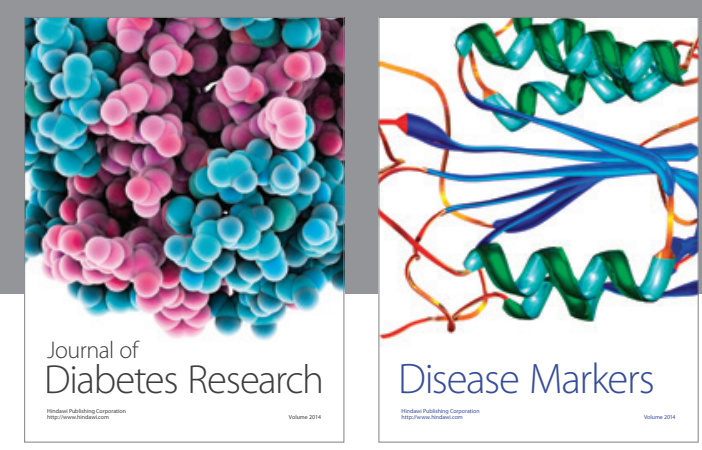

Disease Markers
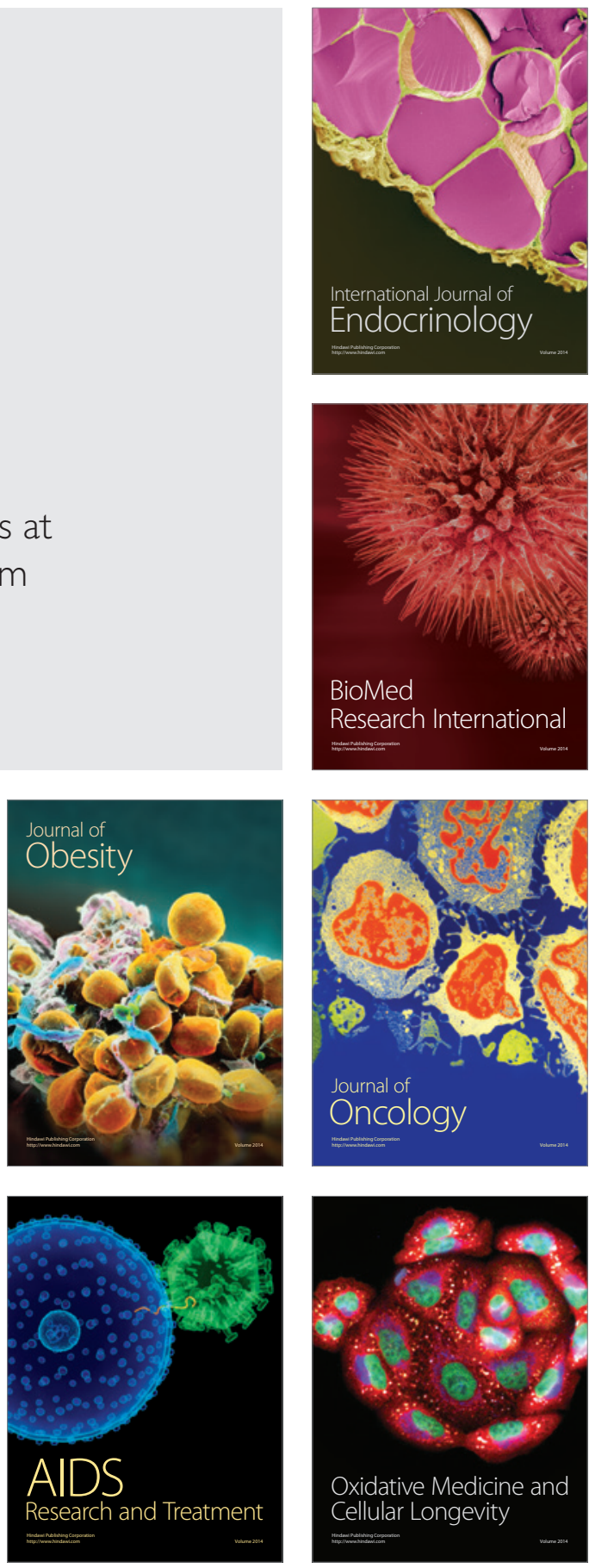